\title{
CHANGES IN ATMOSPHERIC DISPERSION POTENTIAL ACROSS THE SW CAPE COAST
}

\author{
Mark Jury \\ Oceanography Dept, Univ Cape Town, Rondebosch, 7700
}

\begin{abstract}
Changes in the potential for dispersion of atmospheric pollutants across the SW Cape coast, to the northeast of Cape Town, are analysed using case studies of $10 \mathrm{~m}$ meteorological network and doppler acoustic sounder data. The analysis focuses on summer fair weather inversion conditions associated with coastal lows, and cases distinguish between SSE trade winds and weaker WSW seabreezes. The more common SSE wind regime was characteristed as a topographically channelled low level $(300 \mathrm{~m})$ jet. The spatial distributions of air temperatures and horizontal wind deviations were closely related and acrosscoast gradients in the first $10 \mathrm{~km}$ exceeded $5^{\circ} \mathrm{C}$ and $15^{\circ}$, respectively. The acceleration and deflection of SSE wind flow by nearby Table Mountain and a daytime land-sea temperature difference of over $20^{\circ} \mathrm{C}$ accounted for much of the spatial structure. Sounder transects made along a route $12 \mathrm{~km}$ inland over a two week period when seabreezes were prevalent indicated sharp variations in wind direction, speed, turbulence and air temperature in the 0-500 $m$ layer. During lighter seabreeze wind conditions, a thermal internal (convective) boundary layer was well described by sounder transects. The TIBL depth was observed to grow at a rate of 1:20 in the first $5 \mathrm{~km}$ and 1:50 further inland. The meteorological gradients are discussed with regard to the potential for dispersion of atmospheric pollutants in the coastal zone and the ability of towermounted sensors to adequately parameterise such processes.
\end{abstract}

\section{INTRODUCTION}

The perception of a well ventilated atmospheric environment along the coast of southern Africa has had support from climatological studies indicating that strong coast-parallel winds are prevalent (Tyson, et al., 1977, Diab, 1983, and Jury and Guastella, 1987) and from the relatively low concentrations found in recent air pollution monitoring reports (Oxley, 1987). However, the continued growth of population and industry will exert additional pressures on the coastal atmospheric environment, requiring an improved understanding of the dispersion processes. Further impetus for research comes from the fact that many of the existing urban/industrial areas are sited in protected bays where the ventilation potential is limited, for example by Table Mountain, in the case of Cape Town, by Cape Recife at Port Elizabeth and by The Bluff west of Durban.

While urban meteorological studies in the 1960 s have had the desired effect of siting new industries away from the more protected coastal areas, even sophisticated dispersion prediction schemes such as outlined by Jury and Mulholland, (1988) have been unable to parameterise changes in ventilation potential across the coastal zone. Attempts at understanding the structure of the coastal boundary layer have utilised balloon profiling equipment (Keen, 1979) and surface based towers.(VonGogh, 1981). Such data sources offer an inherently restricted view of mixing processes in the coastal atmosphere due to their short time (balloons) and height (towers) scales. Only low flying research aircraft or portable profiling systems such as doppler acoustic sounders, in tandem with the conventional data sources, can solve this problem.
Here results are presented from an effort to understand the four-dimensional nature of the lower atmosphere mounted in the summer of $1985 / 1986$ by the Coastal Meteorology Research Group of the Univ of Cape Town. Results were obtained over an area to the northeast of Cape Town which included the Koeberg Nuclear Power Station and Caltex Refinery.

\section{DATA AND METHODS OF ANALYSIS}

The main source of data was a doppler acoustic sounder which was used in both fixed and mobile mode. In support of the sounder data set, local airport radiosonde information were consulted for temperature structure and surface network data were available from a $20 \times 20 \mathrm{~km}$ area to the northeast of Cape Town.

In the summer of $1985 / 86$ a Remtech Doppler Acoustic Radar (sounder) was located approximately $10 \mathrm{~km}$ to the north of Cape Town, next to the Caltex Refinery (as indicated by the dot in Figure 1). The sounder was sited at an elevation of $30 \mathrm{~m}, 4 \mathrm{~km}$ from the west coast, in an environment surrounded by low lying marshes with a very gradual upward slope to the ENE. Wind and turbulence profiles were obtained every 15 minutes with a vertical resolution of $50 \mathrm{~m}$ from $50-1000 \mathrm{~m}$. Sounder data, consisting of horizontal wind direction and speed, horizontal wind deviation (sigma theta), vertical wind and vertical wind deviation (sigma W) were then processed into hourly averages and listed chronologically for inspection. Performance of the sounder was $100 \%$ up to $300 \mathrm{~m}$, but gradually degraded to $50 \%$ by the $800 \mathrm{~m}$ level. Data availability was erratic $(73 \%$ over a 2 year 


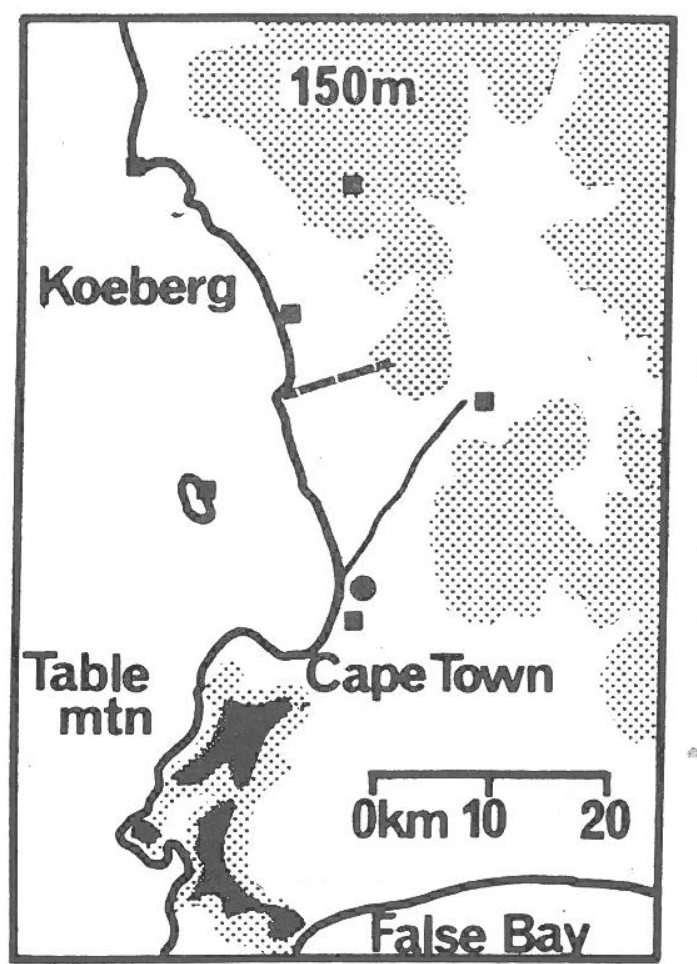

Figure 1

period) due to operator inexperience and sounder malfunction, so potential case studies had to be screened against sounder data availability before final selection and analysis.

Profiles of wind, temperature, and dewpoint were available from radiosonde ascents at DFM airport at 12 hourly intervals to describe changes in upper wind flow and temperature structure, hence atmospheric stability. Surface data were obtained from an automatic weather station network operated by the Koeberg Nuclear Power Station as part of an Emergency Response Facility (Jury and Mulholland, 1988). The six stations (shown by the squares in Fig 1) provided horizontal wind vectors, standard deviations of wind and air temperatures at hourly intervals for matching with the sounder data set. To highlight the mesoscale structure of the surface wind field, $10 \mathrm{~m}$ winds were interpolated onto a $5 \mathrm{~km}$ grid. Centred differences were computed for the wind vorticity $(d v / d x-d u / d y)$ and wind divergence $(d u / d x+d v / d y)$ and contoured in units of $10^{-4} \mathrm{~s}^{-1}$. The vorticity of the wind is defined as the rotational component, while divergence is the stretching and splitting component. At the meso-scale $(10-100 \mathrm{~km})$, both of these parameters can be viewed as symptoms of the surface wind. For example a horizontally uniform wind will contain no mesoscale pattern of vorticity or divergence. If a surface wind field is topographically steered, however, a pattern may develop and repeat itself, particularly where winds are unevenly obstructed or accelerated by mountains.

Cases were selected specifically for inversion conditions, when low mixing heights and sharp acrosscoast changes in dispersion potential were expected. Data were analysed for two types of weather settings: the pre-coastal low, shallow, SSE wind and the fair weather, pre-frontal, seabreeze. These meteorological regimes coincide with summer-time peaks in the cycle of air pollution (Oxley, 1987). A screening procedure (Jury and Spencer-Smith, 1988) was used to ensure the consistency of selected cases. For the shallow SSE wind regime this included identifying a nocturnal acceleration of wind in the lee of Table Mountain. A case was defined when wind speeds at Robben Island, leeward of Table Mountain, exceeded $10 \mathrm{~m} \mathrm{~s}^{-1}$ between 21 h00 and 03h00. In addition, the synoptic weather pattern required by the shallow SSE regime was that of a high pressure cell ridging to the southeast of Cape Town and a coastal low to the north, as in Figure 2. Concurrent sounder data were available for the period 00h00 18 to $12 \mathrm{~h} 0020$ November 1985 , when shallow SSE winds gradually gave way to the passage of a coastal low. In the case of the seabreeze, the criteria for selection included reduced upper winds, warm $\left(>22^{\circ} \mathrm{C}\right)$ inland temperatures, directions in the range $210-290^{\circ}$, hourly speeds of $>2.5 \mathrm{~m} \mathrm{~s}^{-1}$ and a daily averaged speed of $<6 \mathrm{~m} \mathrm{~s}^{-1}$. For the climatology studies nine seabreeze cases were analysed over the diurnal cycle, the results of which are discussed in section 3 and provided in detail by Jury and SpencerSmith (1988).

To obtain cross sections of the seabreeze, the sounder was mobilised from 20 March to 10 April 1986 and transported along a line $12 \mathrm{~km}$ inland from Melkbosstrand, (dashed line in Fig 1). Vertical profiles to $500 \mathrm{~m}$ were obtained at about $4 \mathrm{~km}$ intervals between the hours of $12 \mathrm{~h} 00$ and $14 \mathrm{~h} 00$. Simultaneously, air temperature profiles were made to the $100 \mathrm{~m}$ level using a kite-borne thermistor system. Radiosonde profiles and surface network data were available as outlined above. Transects were selected for three days, 27 March, 3 and 4 April, 1986 when seabreezes blew across the coast and thermal internal boundary layers formed. Height $(0-500 \mathrm{~m})$ versus distance (0-10 km inland) plots were made for the wind speed, direction, sigma theta and sigma $\mathrm{W}$ parameters. The profile data were contoured and care was taken to remove spurious data caused by noise from the power generator. It should be noted that some changes with time could have contaminated these across-coast "snapshots". During the 2-3 hours it took to complete the transect, the seabreeze underwent a $-20^{\circ}$ rotation, while other parameters similarly 
varied by $10-20 \%$. Air temperatures obtained from the kite system were similarly contoured, but only to the $100 \mathrm{~m}$ level owing to horizontal wind drag on the kite. In addition, data from the two surface stations located on each end of the transect were plotted in time, and network data were plotted in space to show the distribution of meteorological variables in all fourdimensions. Together these analyses identify sharp across-coast changes in the dispersion meteorology which occur over this portion of the SW Cape.

\section{CLIMATOLOGY AND BACKGROUND}

Horizontal structure within the inversion capped flows can be primarily attributed to the varied topography of the SW Cape coast (Figure 1). Much of the coast is oriented $340-160^{\circ}$ and the interior plateau rises to more than $500 \mathrm{~m}$ in a distance of less than $100 \mathrm{~km}$. Isolated mountains face the sea next to Cape Town, but topographic variations are smoother to the northeast, the terrain rising to about $200 \mathrm{~m}$ some $15 \mathrm{~km}$ inland. In summer oceanic upwelling reduces sea surface temperature to below $13^{\circ} \mathrm{C}$. Hence sharp land-sea temperature differences of order $20^{\circ} \mathrm{C}$ are characteristic of this coastal zone.

Numerous studies have linked the larger weather setting to the four-dimensional structure of the lower atmosphere (Redding, et al., 1982, Jury and SpencerSmith, 1988). Hence it is useful to review how the positioning of the larger weather systems influences ventilation potential.

The summer climatology affecting the SW Cape coast is dominated by strong SSE winds driven by the South Atlantic High and an interior thermal low. The SSE wind occurs in two modes (Jury, 1980), deep and shallow. In deep SSE flow, cold air advection takes place, winds rotate to $\mathrm{SW}$ aloft and the subsidence inversion is elevated. Such a flow regime is synonymous with the tablecloth over Table Mountain, coincides with efficient ventilation and exhibits a degree of persistence, thus predictability (Jury and Guastella, 1987). When the South Atlantic high pressure cell is ridged to the south of Africa, as in Figure 2 , the inversion descends and strengthens, thus restricting the depth of SSE flow and preventing the dispersion of atmospheric pollutants.

Periodically the pressure gradient between the offshore high and interior low is modulated by waves in the westerlies. The result is a sequence of high pressures, interrupted by coastal lows and cold fronts. As a coastal low moves through the area the inversion drops from a mean height of $1200 \mathrm{~m}$ (Preston Whyte, et al., 1977) to $600 \mathrm{~m}$ (Heydenrych,

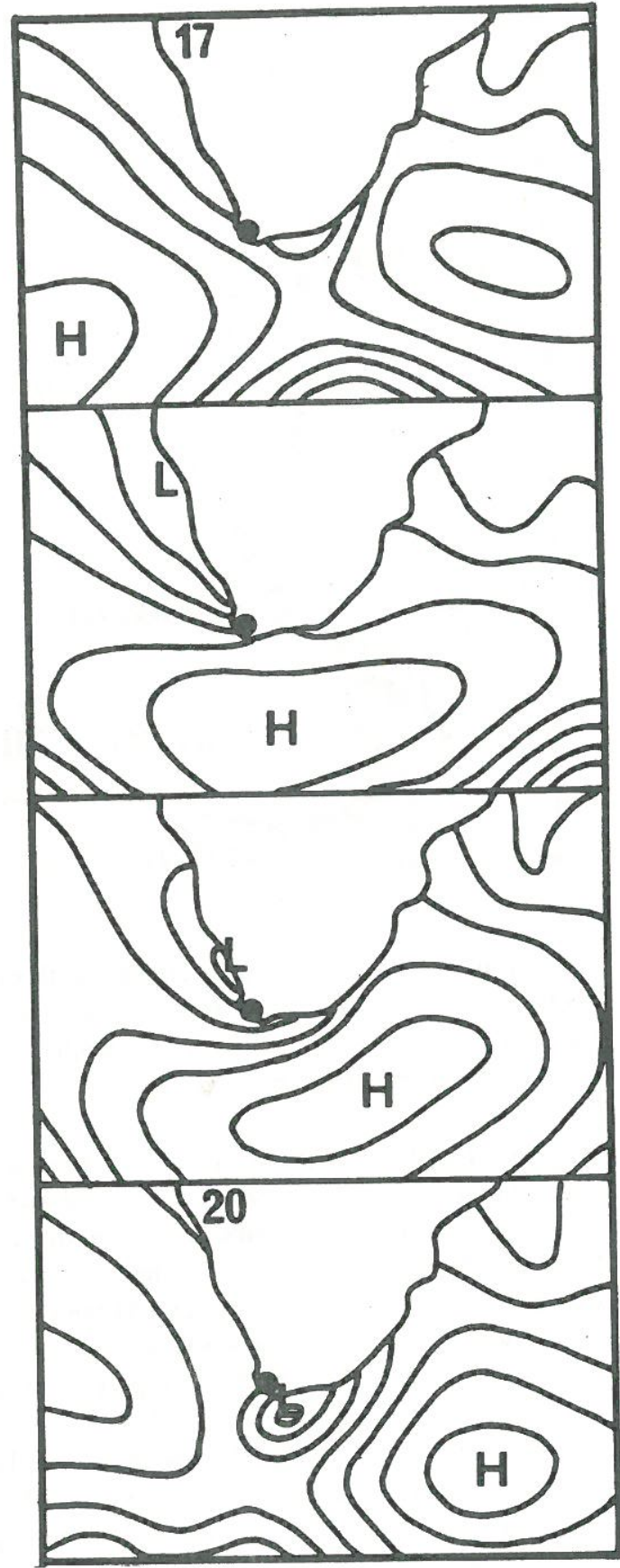

Figure 2

1987), thereby restricting ventilation while at the same time enhancing across-coast gradients in meteorlogical parameters which control mixing, (ie wind, vertical temperature structure, and turbulence). In chronological sequence, a westerly trough then approaches the SW Cape coast and the associated pressure col (a region of little horizontal pressure change) causes light onshore winds. Together the shallow SSE winds $(35 \%)$ and seabreezes $(25 \%)$ make an approximate $60 \%$ contribution to the summer surface wind 
climatology and contain the least potential for dispersion, particularly in the Cape Town basin, where Table Mountain blocks the wind. Deep (>1 km) SSE winds (30\%) and N-NW winds (10\%) make up the remainder of summer weather and are characterised by stronger wind speeds and relatively clean air.

Keen (1979) first analysed the structure of west coast seabreezes using simultaneous pilot balloon releases along an inland transect. Seabreezes were found to be 5-7 $\mathrm{m} \mathrm{s}^{-1}$ in the $100-1000 \mathrm{~m}$ layer with $2-3 \mathrm{~m} \mathrm{~s}^{-1}$ return flow aloft. Seabreezes penetrated over $20 \mathrm{~km}$ inland and therefore affected most of the pollution sources in the SW Cape area. Keen (1979) and Jury (1984) have found that the seabreeze of the west coast often converges with the seabreeze from the south coast (False Bay). Such a convergence over the Cape Town industrial district may concentrate the air pollutants along a line extending eastwards from Table Mountain. Redding et al. (1982) has investigated the relationship between synoptic weather forcing and seabreezes near Koeberg. A frequency of $23 \%$ was found during summer. When pressure gradients exceeded $10^{-2} \mathrm{hPa}$ $\mathrm{km}^{-1}$, seabreezes were observed to be masked by the stronger along-coast flow. The seabreezes studied by Redding et al., (1982) were of an average depth of $250 \mathrm{~m}$, considerably shallower than that found by Keen (1979).

An understanding of the vertical structure and timing of west coast seabreezes was offered by Jury and Spencer-Smith (1988) through a composite analysis of seabreezes profiled by sounder at the Caltex refinery site during the summers of 1984-1986. Common traits of the SW Cape seabreeze included: a depth of $430 \mathrm{~m}$, a mean speed of $6.6 \mathrm{~m} \mathrm{~s}^{-1}$ occurring at $13 \mathrm{~h} 30$ from a direction of $261^{\circ}$ near the $150 \mathrm{~m}$ level, a time of influence extending from $09 \mathrm{~h} 00$ $16 \mathrm{~h} 00$, and a penetration of over $20 \mathrm{~km}$ inland. Turbulence structures associated with the west coast seabreeze were also described. The sigma theta pattern was dominated by a line of high values preceding the front edge of the seabreeze air mass as it advanced inland, first affecting the surface at $08 \mathrm{~h} 00$ and the $600 \mathrm{~m}$ level by $11 \mathrm{~h} 00$, giving the idea of a seawards-leaning wedge moving inland at about $2 \mathrm{~m} \mathrm{~s}^{-1}$. Before sunrise, subsidence and low vertical turbulence prevailed. After the seabreeze had moved across the sounder site, vertical uplift and convection gradually increased from the surface upwards in time, representing the growth of the thermal boundary layer. Using aircraft cross sections, Jury (1984) and Jury and Guastella (1987) have characterised the upward slope of the surface warmed, unstable layer. During shallow SSE winds, the vertical structure of this unstable layer over the coast north of Cape Town is complicated by the wake of Table Mountain. To establish upper level forcing during seabreeze cases radiosonde data from D F Malan airport were consulted. A NW wind of over $5 \mathrm{~m} \mathrm{~s}^{-1}$ was observed at the top of the boundary layer, $2-5^{\circ} \mathrm{C}$ inversions were common in the range 834 $958 \mathrm{hPa}$ and it was concluded that west coast seabreezes contained little potential for recirculation. Surface synoptic pressure analyses suggested the presence of a weak coastal low pressure cell in most cases. The seabreeze studies of Jury and SpencerSmith (1988), while advancing our knowledge, have shed little information on the across-coast structure of seabreezes. To fill this gap, a method of obtaining sounder profiles along an inland transect was formulated (Comrie 1986), the results of which are reported in section 4.2 .

\section{RESULTS}

\subsection{The structure of shallow SSE winds}

A case study sequence extending from $00 \mathrm{~h} 00$ 18 November to $12 \mathrm{~h} 0020$ November 1985 is used to illustrate across-coast changes in meteorological conditions which occur during shallow SSE flow. Figure 3 shows the mesoscale wind

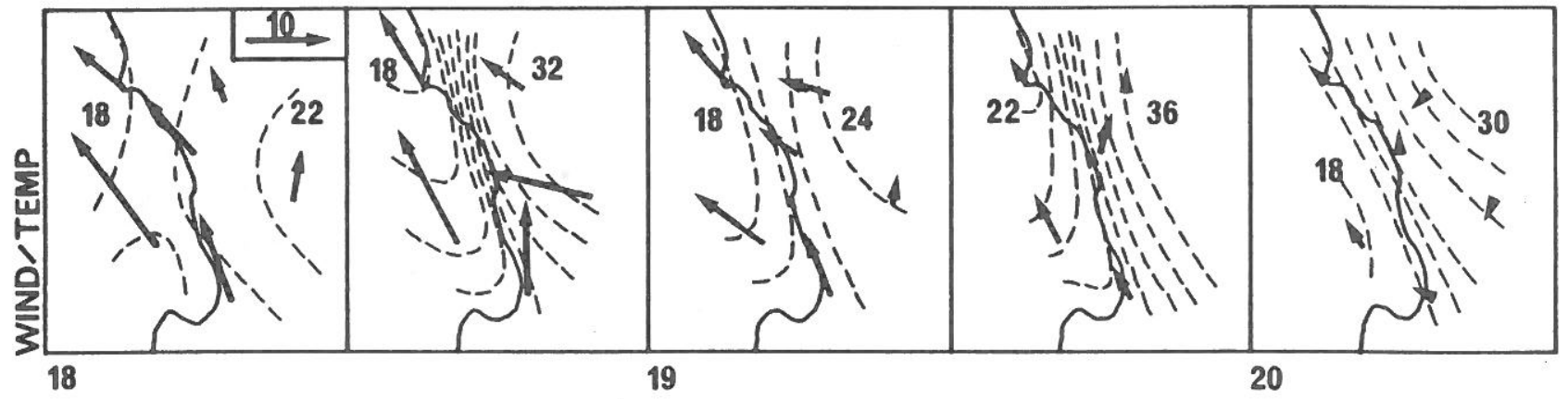

Figure 3 


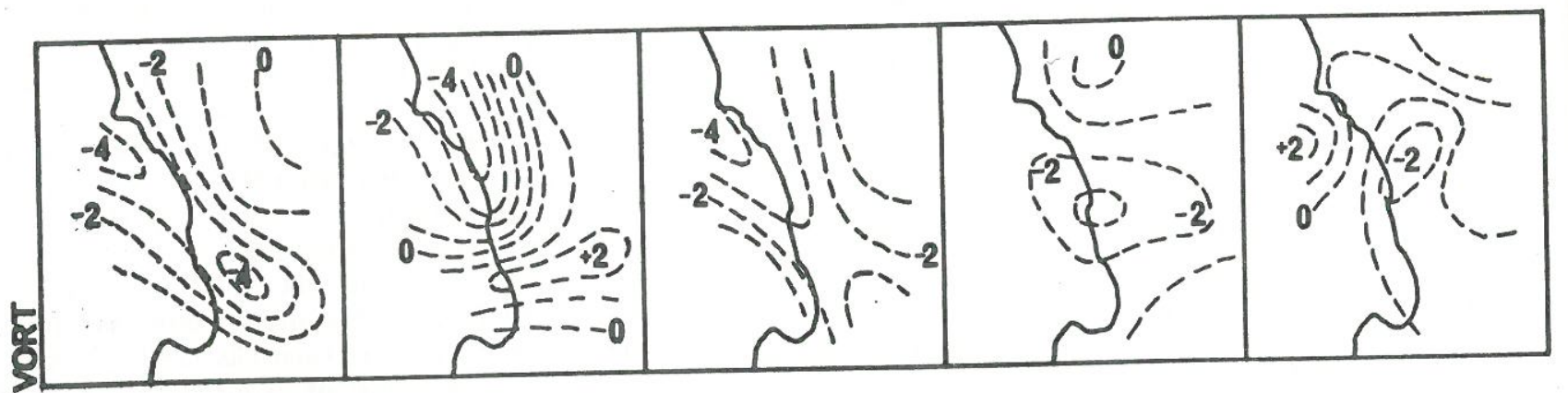

Figure 4

and temperature field analyses at 12 hourly intervals for this period. Moving through the sequence (left to right) it can be seen that strongest SSE winds were observed at the offshore island and speeds (arrow lengths) diminished inland and to the north. Air temperature gradients were more relaxed during the nights, but reached $10^{\circ} \mathrm{C}$ in the first $10 \mathrm{~km}$ of the coast at $12 \mathrm{~h} 00$ on both days, indicating the formation of a convective boundary layer. Wind speeds gradually diminished after $12 \mathrm{~h} 00$ on 19 November with the approach of the coastal low. By mid-day on the 20th seabreezes were prevalent.

The horizontal structure of winds during the case study sequence is well illustrated through analysis of vorticity and divergence. The vorticity distribution for the shallow SSE wind sequence is shown in Figure 4. Throughout the period, negative cyclonic vorticity was maintained at $-210^{-4} \mathrm{~s}^{-1}$, a relatively extreme level. The structure of the cyclonic maximum exhibited a NNW-SSE alignment parallel to the wind flow through the middle of the study area. Highest negative values were evident over the coast to the north of Cape Town and can be attributed to the acceleration of SSE wind flow around the eastern edge of Table Mountain. Areas of positive, anticyclonic vorticity intruded into the study area only when the inland sites experienced bursts of berg wind flow from the east and when SSE winds abated towards the end of the sequence.

The pattern of divergence was not persistent, however, the 00h00 18 November 1985 divergence field could be interpreted as most similar to the mean summer climatology. Positive divergence dominated the pattern indicating a spreading of wind streamlines from south to north over the study area. This pattern of divergence was repeated on the following night. During the day the flow was largely convergent (negative) due to the influence of berg winds at the inland sites and seabreezes at the coast. The upward 1:100 slope of the terrain, in combination with a sharp vertical temperature differential $\left(91^{\circ} \mathrm{C}\right.$ over $80 \mathrm{~m}$ at Koeberg) enabled the convergence and raises the possibility of pollutant accumulation.

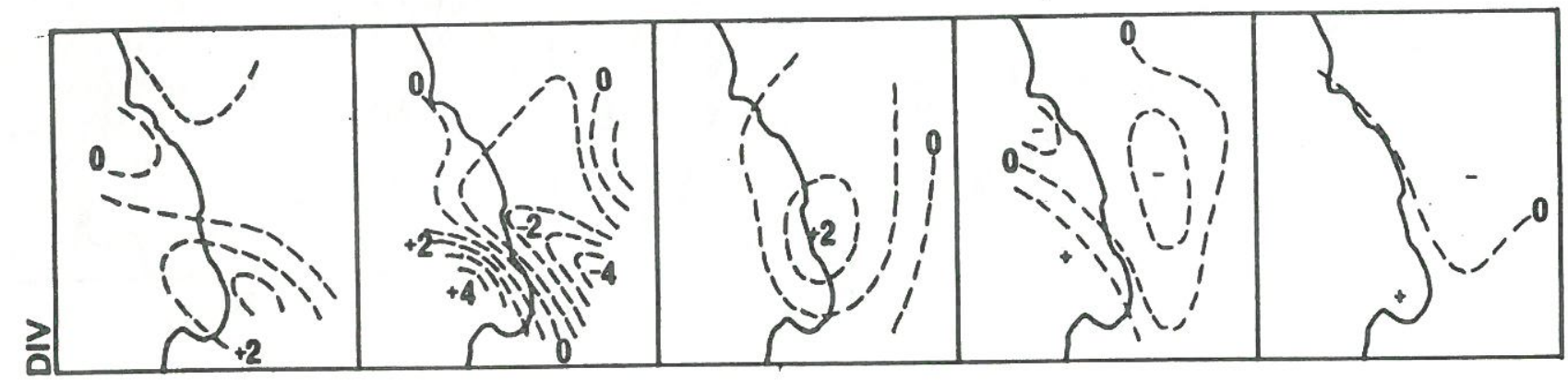

Figure 5 
Vertical profiles of temperature and dewpoint from the local airport radiosonde and wind and turbulence from the sounder at Milnerton are shown over the case study sequence in Figure 6. The profiles are numbered $1-5$ to correspond with the horizontal maps previously discussed. It is evident from the radiosonde temperature data that inversion conditions were maintained throughout the sequence. Intense daytime heating merely caused the profile to become isothermal. Dewpoints were relatively low, ranging from $15^{\circ} \mathrm{C}$ at the surface $(1000 \mathrm{hPa})$ to near $5^{\circ} \mathrm{C}$ above $950 \mathrm{hPa}$. Dewpoint depressions of over $20^{\circ} \mathrm{C}$, indicated increased subsidence associated with the approaching coastal low (Heydenrych, 1987).

Sounder (time, height) profiles of direction, speed, sigma theta, $W$ and sigma $W$ are illustrated in the middle and right panels of Figure 6. Directions changed from S $\left(180^{\circ}\right)$ near the surface to $\mathrm{E}$ aloft. Upper winds were from the NW early in the sequence and gradually invaded the surface by the end of the sequence. Sounder wind directions were compared with radiosonde winds and discrepancies of $-25^{\circ}$ were noted in profiles $1-3$ in the $0-500 \mathrm{~m}$ layer. Above the inversion, NW flow recorded by the sounder was seen to be more northerly from the radiosonde profile. Comparisons for profiles 4 and 5 show that radiosonde winds were $+25^{\circ}$ greater than sounder winds for most levels. Sounder data indicated a burst of NE winds in the 300$500 \mathrm{~m}$ layer at $12 \mathrm{~h} 0019$ November 1985, presumably heralding the arrival of the coastal low. The radiosonde did not register the NE flow and it is not certain whether such variances can be attributed to technology or position. The comparison also raises questions concerning the validity of using D F Malan airport radiosonde data as a uniform $300 \mathrm{~m}$ level wind vector in the dispersion prediction scheme supporting Koeberg (Mulholland and Jury, 1987).

Sounder wind speed profiles shown in the middle panel of Figure 6 reveal the gradual decay of a low level jet, a highly dispersive meteorological mechanism. Peak wind speeds dropped at a rate of $100 \mathrm{~m}\left(12 \mathrm{hr}^{-1}\right)$ from $17 \mathrm{~m} \mathrm{~s}^{-1}$ at $300 \mathrm{~m}$ on the 18 th to $12 \mathrm{~m} \mathrm{~s}^{-1}$ at $100 \mathrm{~m}$ on the 19 th. By 00 h00 on 20 November the profile had adopted a shape typical of westerly flow, increasing aloft from $2 \mathrm{~m} \mathrm{~s}^{-1}$ at $50 \mathrm{~m}$ to $6 \mathrm{~m} \mathrm{~s}^{-1}$ at $500 \mathrm{~m}$. Vertical profiles of sigma theta were not entirely conclusive, but the trend was towards increasing values with time. Profiles 1-3 contained sigma theta values of around $5^{\circ}$, whereas profiles 4 and 5 showed peaks of over $20^{\circ}$ under calmer conditions. The vertical component contained within the SSE wind was found to be sharply downwards (negative) in the mean (see Jury and Reason 1989 for a discussion of this feature). Profiles 1-3 exhibited most negative components with values reaching $-1 \mathrm{~m} \mathrm{~s}^{-1}$ between 200 and $500 \mathrm{~m}$. Profiles 4 and 5 saw a gradual reduction in downwards components. By $00 \mathrm{~h} 00$ on 20 November the low level subsidence had abated and was replaced by uplifted flow, owing to the terrain slope relative to the onshore wind direction. Sigma W profiles on the right side of Figure 6 indicate the height of the convective boundary layer and show that greatest vertical variances were contained in the lowest layers during daytime heating. The vertical profile of sigma $\mathrm{W}$ became reduced at a rate of $-8 \mathrm{~cm} \mathrm{~s}^{-1}$

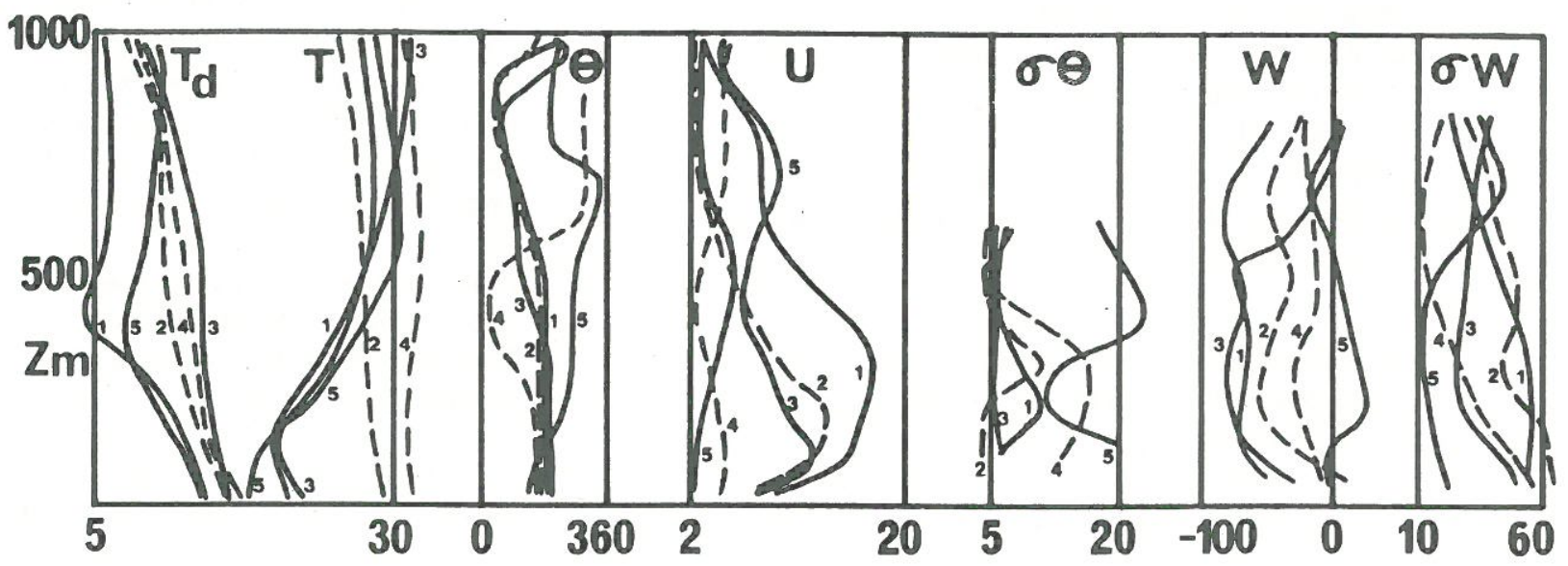

Figure 6 
$(100 \mathrm{~m})^{-1}$ from $60 \mathrm{~cm} \mathrm{~s}^{-1}$ at the surface to $10 \mathrm{~cm} \mathrm{~s}^{-1}$ at $800 \mathrm{~m}$. The sigma $\mathrm{W}$ profile changed shape on the 20th when low values were found near the surface. Generally, lower speeds at the end of the sequence resulted in less vertical variances.

With sounder and radiosonde profiles, the potential for the topographic channelling of winds can be assessed using the Froude number $\mathrm{F}=\mathrm{U} / \mathrm{N} \mathrm{h}$, where $\mathrm{U}$ is the maximum boundary layer wind speed, $h$ is the mountain elevation, and $\mathrm{N}$ is buoyancy frequency from the vertical temperature gradient. A buoyancy frequency of $10^{-2} \mathrm{~s}^{-1}$ is obtained from profile 2 in Figure 6, so the $\mathrm{F}$ number was close to unity for an $\mathrm{h}$ of $1000 \mathrm{~m}$ and a $\mathrm{U}$ of more than $10 \mathrm{~m} \mathrm{~s}^{-1}$. Thus a supercritical acceleration of flow was possible in the vicinity of Table Mountain and topographic channelling was limited. Later in the sequence, the $\mathrm{N}$ value (for profiles 3,5 ) approached $210^{-2}$, while the U was reduced. The $F$ number fell below unity and topographic channelling by hills only $100 \mathrm{~m}$ high was possible. Hence the potential for across-coast changes in the dispersion meteorology became increased through the sequence, as the coastal low approached and the depth of SSE wind flow abated.

\subsection{Across-coast changes in the seabreeze}

Unlike the more persistent and dispersive SSE trade winds, the seabreeze has more significant consequences for air pollution in the coastal boundary layer. The seabreeze can cause rapid transitions in wind directions and stabilities as it advances inland in the morning and decays in the afternoon. Air pollution monitoring data collected near the Caltex refinery (Oxley, 1987) show that seabreezes which develop following a spell of SSE winds, coincide with increases in $24 \mathrm{hr}$ averaged $\mathrm{NO}_{\mathrm{x}}$ values from 100 to $300 \mathrm{ug}$ $\mathrm{m}^{-3}$ and $\mathrm{SO}_{2}$ values from 10 to $40 \mathrm{ug} \mathrm{m} \mathrm{g}^{-3}$. It is therefore instructive from an air pollution perspective to describe the characteristics of seabreezes near Cape Town.

The across-coast structure of the seabreeze is described for three cases on 27 March, 3 and 4 April 1986. The sounder wind speed, direction, sigma theta and sigma $\mathrm{W}$ cross sections for the three case studies days are shown in Figure 7 in relation to inland distance. Temperature cross sections and surface trends are shown in Figure 8 , while the horizontal variability is analysed in Figure 9, as in Fig. 3. At the coast, very low wind speeds were characteristic in the 50-300 m layer in all cases. Wind directions were westerly at the surface except for the 3 April case where more southerly flow prevailed. Considerable wind shear was observed over the coast as illustrated by the vertical packing of direction isolines. Interpreting sounder data further inland, an increase in wind speed was found in every case. Strongest speeds were observed at $8-10 \mathrm{~km}, 5-6 \mathrm{~km}$ and $12 \mathrm{~km}$ inland over the three cases, respectively. Speeds were strongest in the 50-300 m layer where directions were most perpendicular $\left(250^{\circ}\right)$ to the coast. The sigma theta structure increased inland, above $30^{\circ}$ on the 27 th and over $25^{\circ}$ on the 4 th. The case of 3 April exhibited low sigma theta values near the surface.

The TIBL is often identified as the region where thermals rise off the heated land surface. The vertical variance parameter, sigma $\mathrm{W}$, should therefore best define the TIBL. Cases with classic onshore flow on 27 March and 4 April exhibited an increase in sigma $W$ values both inland and towards the surface. Low vertical variances of order $10 \mathrm{~cm} \mathrm{~s}^{-1}$ were characteristic at the coast and over $300 \mathrm{~m}$ above ground level. Yet only $10 \mathrm{~km}$ inland, vertical variances exceeded $60 \mathrm{~cm} \mathrm{~s}^{-1}$ in the surface layer. The slope of the TIBL, as identified by the $40 \mathrm{~cm} \mathrm{~s}^{-1}$ isoline was parabolic, as expected from theory (Steyn and Oke, 1982), with an approximate trend of $1: 50$ on the 27th and closer to $1: 20$ on the 4th, (terrain aspect is $1: 100)$. In the 3 April case, high sigma W values extended right across the transect in the 200$400 \mathrm{~m}$ layer and unusually low values were observed near the surface, perhaps indicating that the TIBL was disrupted by SSE winds aloft. The $\mathrm{x}, \mathrm{z}$ structure of temperature and temporal trends are outlined in Figure 8 and similar results were evident for all three transects. Coolest temperatures were found in the $20-40 \mathrm{~m}$ layer over the coast. Isotherms were almost vertically aligned in the first $5 \mathrm{~km}$ on the $3 \mathrm{rd}$ and 4 th, while on the 27th a cool tongue of air penetrated inland underneath a warm stable layer. Further inland, the upwards flux of surface sensible heat created a shallow warm layer. Isotherms were sloped less steeply than the sigma W pattern. Much of the structure can be attributed to the land-sea surface temperature difference which was of the order of $20^{\circ} \mathrm{C}$ $(10 \mathrm{~km})^{-1}$, ie $32^{\mathrm{O}}-12^{\circ} \mathrm{C}$. 

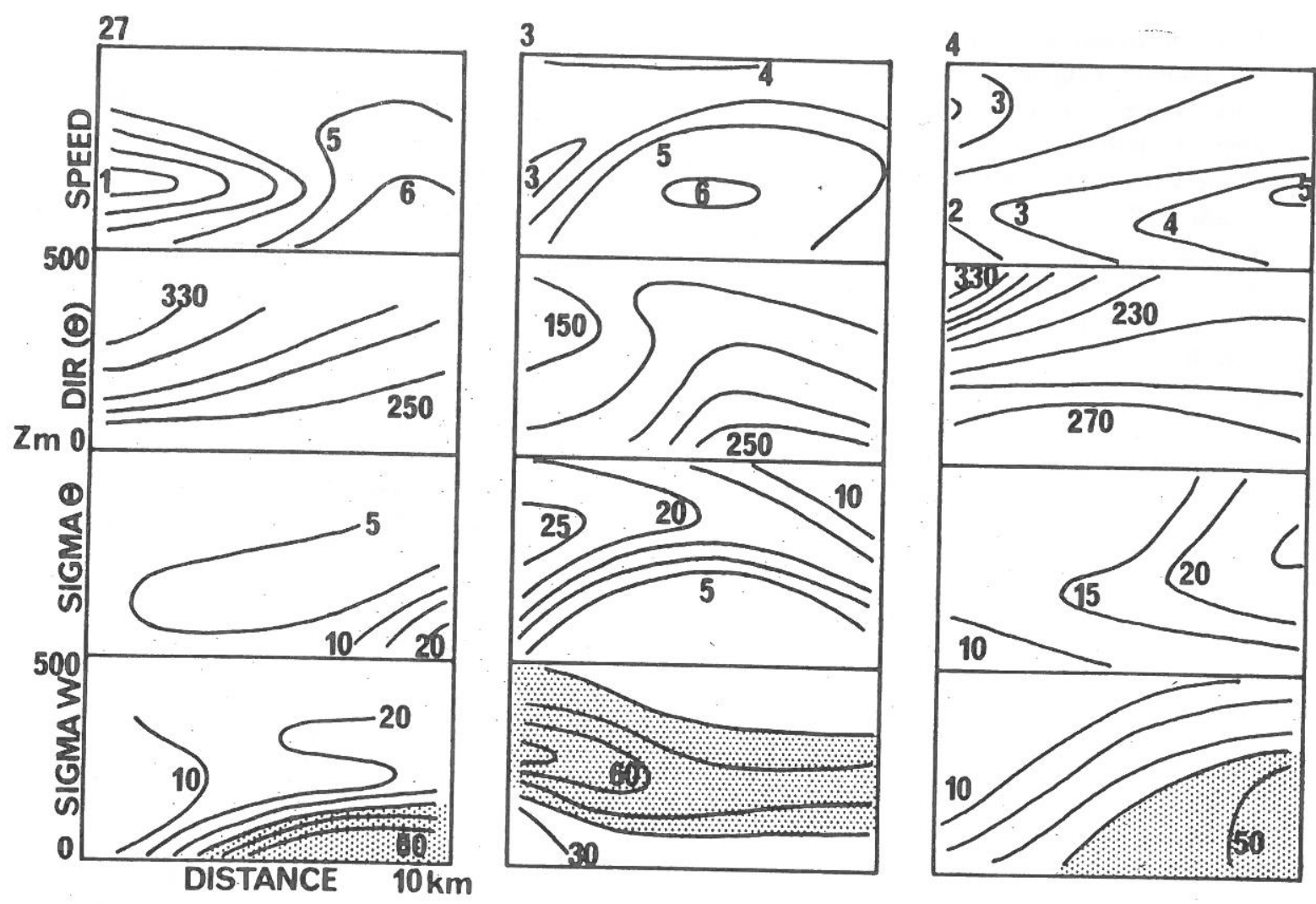

Figure 7
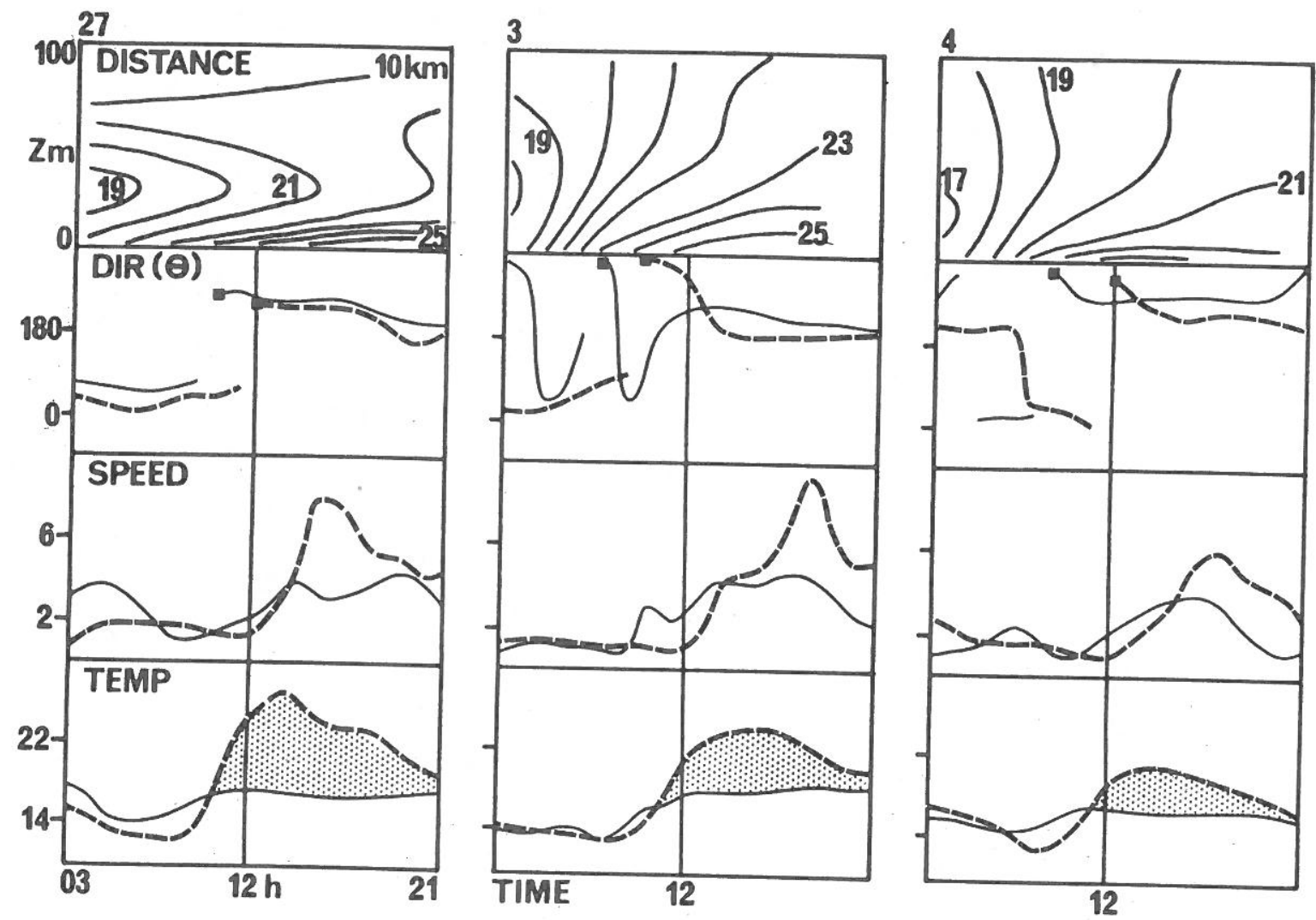

Figure 8 
Temporal trends were quantified at each end of the transect (Figure 8) and similar patterns were evident for the three cases. Wind directions changed from offshore to onshore first at the coast and then inland between $08 \mathrm{~h} 00$ $12 \mathrm{~h} 00$, with a lag of $2-3$ hours over the $15 \mathrm{~km}$ distance, giving a $2 \mathrm{~m} \mathrm{~s}^{-1}$ rate of advance for the seabreeze. Air temperatures at the $10 \mathrm{~m}$ level varied by $10^{\circ} \mathrm{C}$ at the inland site, but only $4^{\circ} \mathrm{C}$ at the coast. A maximum E-W temperature differential of $8^{\circ} \mathrm{C}$ was observed on the 27 th at $14 \mathrm{~h} 00$. This was immediately followed by an increase in surface wind speed, initially at the coast site and then a few hours later at the inland site as the seabreeze ad- vanced. Wind speeds at the inland site showed sudden increases in the late afternoon on the 3 rd and in mid-afternoon on the 27 th and 4 th due to the anti-clockwise rotation of the seabreeze aligning with the local Diep River valley. The seabreeze appeared to decay simultaneously over the entire coastal zone just before sunset rather than to retreat in an organised fashion.

Spatial structure for the transect days was analysed using the network data. 12h00-13h00 averages of winds, temperatures and sigma thetas are plotted in Figure 9 and indicate that a degree of topographic control was exerted
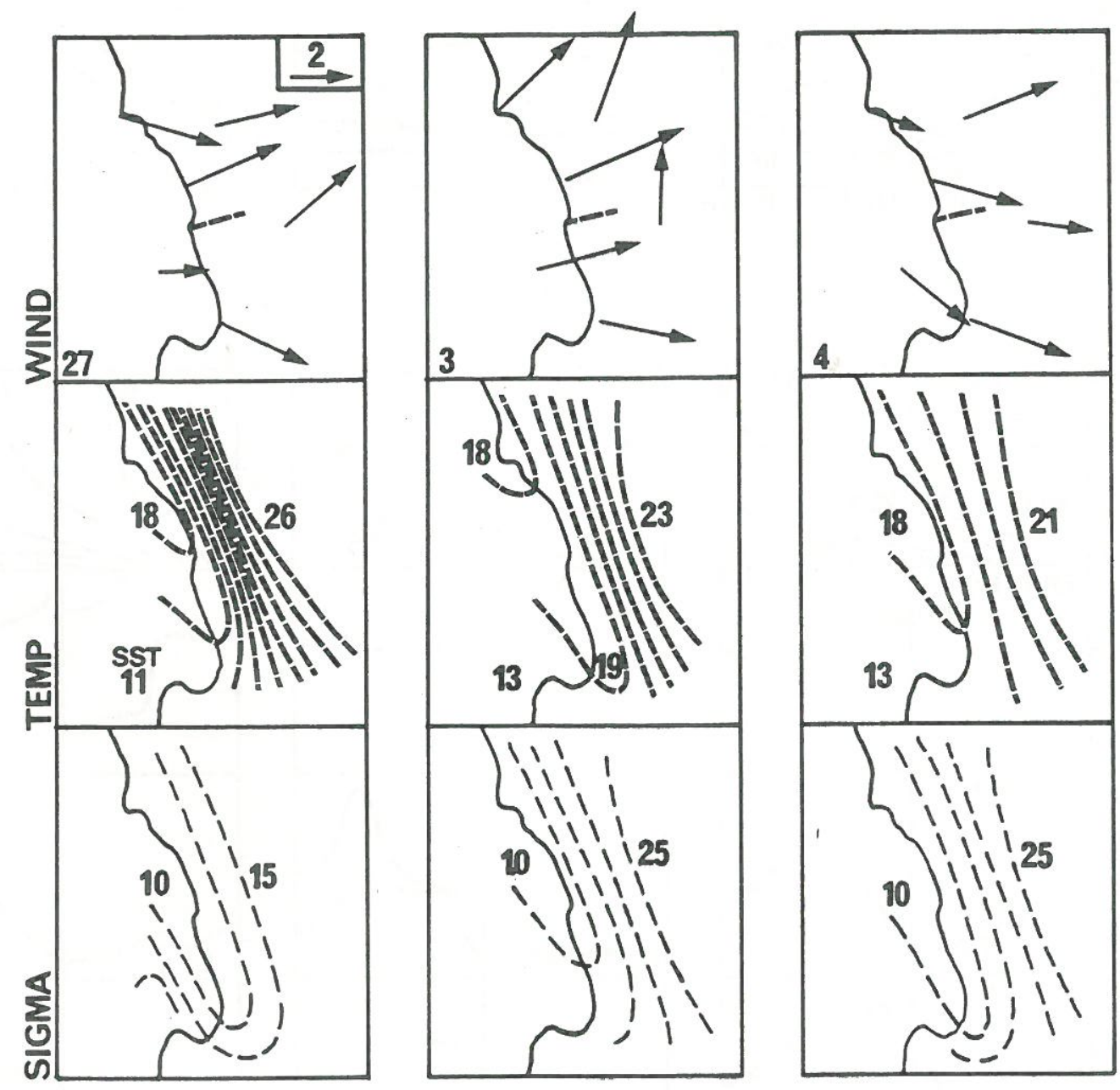

Figure 9 
on the seabreeze. Patterns for air temperature and sigma theta were consistent and repeated through the cases. An area of low temperature and turbulence extended down the coast from the NW (see also Jury and Guastella, 1987, Fig 2). Highest sigma theta values were located inland and to the SE. The gradients for temperature appeared to relax through the case study sequence, being of order $8^{\circ} \mathrm{C} 10 \mathrm{~km}^{-1}$ on the 27 th, but only $2^{\circ} \mathrm{C} 10 \mathrm{~km}^{-1}$ on the 4 th as a result of reduced insolation ( $200 \mathrm{~W} \mathrm{~m}^{-2}$ less) and higher sea surface temperatures $\left(3^{\circ} \mathrm{C}\right.$ more).

It is significant that the seabreezes of the 27 th and 4 th were of similar strength, even though the primary forcing function, the land-sea temperature difference, was reduced from $19^{\circ}$ to $12^{\circ} \mathrm{C}$. The relaxation of seabreeze forces on the 4 th was further compounded by a reduction in upper level westerlies. $850 \mathrm{hPa}$ winds were from $310^{\circ}$ at $8.0 \mathrm{~m} \mathrm{~s}^{-1}$ on the 27 th and from $285^{\circ}$ at only $3.4 \mathrm{~m} \mathrm{~s}^{-1}$ on the 4 th. Thus variations in the strength of the seabreeze are not easily understood or predicted.

\section{SUMMARY}

Detailed, four-dimensional observations have been presented for the shallow SSE wind and the seabreeze. Within $10 \mathrm{~km}$ of the coast sharp gradients are found in the meteorological conditions which control the dispersion of atmospheric pollutants. The spatial distribution of the SSE wind was strongly influenced by local mountain features, particularly when the depth of flow was reduced by an approaching coastal low. The SSE winds accelerated over Table Mountain preferentially at night and created patterns of positive divergence and cyclonic vorticity conducive to dispersion. With a lowering of the subsidence inversion, the local mountains obstruct shallow SSE winds and air pollution levels may rise to unhealthy levels in the Cape Town basin.

The initiation of a seabreeze circulation depended on the phase relationship between the random synoptic scale pressure "col" preceding a westerly trough, and the regular 24 hour insolation cycle. Across-coast changes in temperatures and vertical turbulence within the seabreeze were characterised by a convective layer (TIBL) which sloped upwards at a rate of $1: 20$ in the first $5 \mathrm{~km}$ and gradually flattened to $1: 50$ thereafter, reaching an equilibrium height of $300-400 \mathrm{~m}$ over $10 \mathrm{~km}$ inland. This means that fumigation would occur at $2 \mathrm{~km}$ inland for coastal emissions with effective stack heights of $100 \mathrm{~m}$
The sounder transects conducted within the seabreeze represent the first time that rapid spatial transitions in dispersion potential have been fully quantified in the coastal zone of Southern Africa. The sounder results cast doubt on the ability of a single $(100 \mathrm{~m})$ meteorological tower to adequately prescribe the parameters necessary for air pollution prediction schemes. $10 \mathrm{~m}$ networks may capture much of the relevant spatial details at the surface, but do not provide a vertical description of upper boundary layer phenomena such as anomalous wind flows and trapping subsidence layers.

A four-dimensional understanding of across-coast changes in dispersion potential, such as provided here and in Comrie (1988), facilitate the testing of air pollution prediction methods which use mesoscale numerical models to interpolate the atmospheric environment. To improve the prediction of air pollution without incurring high costs, it is inevitable that software systems based on sound advice and meaningful research should gradually replace expensive meteorological hardware.

\section{ACKNOWLEDGEMENTS}

I thank Dr C S Keen, formerly of the Univ of Cape Town, and his co-workers C Heydenrych, M Dutkiewicz, A Comrie and $\mathrm{P}$ Lee for collecting, processing and analysing the doppler sounder data. G Sneedon, K Levey and G SpencerSmith are thanked for composite analysis of the sounder data. Eskom is acknowledged for providing the surface network data. I thank the FRD of the CSIR for funding the sounder project.

\section{REFERENCES}

COMRIE, A C. 1986. Thermal Internal Boundary Layer Transects, Data Rep, Env Geogr Sci Dept, Univ Cape Town, 104 pp.

COMRIE, A C. 1988. Growth, structure and prediction of the thermal internal boundary layer, MSc Thesis, Env Geogr Sci Dept, Univ Cape Town, 155 pp.

DIAB, R D. 1983. Wind energy potential over South Africa, Final report to CSIR, Geogr Env Sci Dept, Univ of Natal, $168 \mathrm{pp}$.

HEYDENRYCH, C M. 1987. A climatology of the coastal low in the SW Cape, MSc Thesis, Env Geogr Sci Dept, Univ Cape Town, 135 pp.

JURY, M R. 1980. Characteristics of summer wind fields over the Cape Peninsula upwelling region, MSc Thesis, Oceanogr Dept, Univ Cape Town, 131 pp. 
JURY, M R. 1984. Wind shear and differential upwelling along the SW tip of Africa, PhD Thesis, Univ Cape Town, $164 \mathrm{pp}$.

JURY, M R and L GUASTELLA.. 1987. Coastal wind and dispersion conditions at Koeberg with application to mesoscale forecasting, $S$ Afr J Sci, 83, 435-440.

JURY, M R and M MULHOLLAND. 1988. Coastal dispersion conditions near the SW tip of Africa : a system for evaluation and prediction, $J$ Health Physics, $54,4,421-429$.

JURY, M R and G SPENCER-SMITH. 1988. Doppler sounder observations of trade winds and seabreezes along the African west coast near $34^{\circ} \mathrm{S}, 18^{\circ} \mathrm{E}$, Boundary Layer Met, (in press).

JURY, M R and C REASON. 1989. Extreme subsidence in the Agulhas-Benguela air mass transition, Bound dary Layer Met, 44, 373-405.

KEEN, C S. 1979. Air pollution survey of Greater Cape Town, 4, Rep to Cape Town City Council, $146 \mathrm{pp}$.
MULHOLLAND, M. and M R JURY. 1987. System design for a real-time atmospheric dispersion model, Atm Env, 21, 1059-1072.

OXLEY, D. 1987. Summary of data from automatic air pollution monitors in the Cape Peninsula 1986, Sci Serv Rep, City Eng Dept, Cape Town, 174 pp.

PRESTON-WHYTE, R, R D DIAB and P D TYSON. 1977. Towards an inversion climatology of Southern Africa, part 2, non-surface inversions in the lower atmosphere, $S$ Afr Geogr J, 59, 45-59.

REDDING, S, C NORDEN and D VAN AS. 1982. The relationship between synoptic scale airflow and local wind fields over Duynefontein, PIN-629 (C/V), Atomic Energy Board, Pelindaba.

TYSON, P D, R PRESTON-WHYTE and R D DIAB. 1976. Towards an inversion climatology of Southern Africa, part 1, surface inversions, $S A$ Geogr J, 58, 151-163.

VON GOGH, R. 1981. Aspects of the dispersion climatology of the greater Cape Town Area, Rep Physical Planning Branch, Pretoria.

\section{FIGURES}

FIG 1 - Topographic map of the Cape Town area showing elevations above 150 (light) and $300 \mathrm{~m}$ (dark shaded) and the data network, identified by : surface-squares, sounderdot, transect-dashed line.

FIG 2 - Synoptic surface air pressure analyses for the SSE trade wind-coastal low sequence, 14h00 17-20 November 1985. Contours are at $4 \mathrm{hPa}$ intervals.

FIG 3 - SSE trade wind-coastal low sequence of $10 \mathrm{~m}$ winds and air temperatures $\left({ }^{\circ} \mathrm{C}\right)$ at $12 \mathrm{~h}$ intervals from 00h00 18 November to 00h00 20 November 1985. Wind vector scale is indicated at upper left.

FIG 4 - Wind vorticity analysis from matrix interpolated $10 \mathrm{~m}$ data. Units are $10^{-4} \mathrm{~s}^{-1}$. Negative indicates cyclonic vorticity.

FIG 5 - Wind divergence analysis as in Fig 4. Positive = divergence and implies subsidence through continuity. Negative indicates convergence. Units are $10^{-4} \mathrm{~s}^{-1}$.

FIG 6 - Radiosonde profiles of dewpoint and temperature; and sounder profiles of wind direction, speed, sigma theta, vertical wind (W), and sigma W for $12 \mathrm{hr}$ intervals corresponding to Figs 3-5. Profile $1=00$ h00 18 November profile $5=00$ h00 20 November 1985. Daytime profiles are dashed. Scales are given at the bottom in units from left to right: ${ }^{\circ} \mathrm{C},{ }^{\mathrm{O}}$ from north $\left(180^{\circ}\right.$ is from south $), \mathrm{m} \mathrm{s}^{-1},{ }^{\mathrm{O}}$ horizontal variance, $\mathrm{cm} \mathrm{s}^{-1}$ (negative is subsidence) and $\mathrm{cm} \mathrm{s}^{-1}$ vertical variance.

FIG 7 - Sounder transect height-distance analyses for 12h00-14h00 27 March, 3 and 4 April, 1986 (left to right), showing wind speed, direction, sigma theta and sigma W from top to bottom. The terrain slopes upward to exceed $100 \mathrm{~m}$ at $10 \mathrm{~km}$ inland. All data are shown above ground level. Sigma W values $>40 \mathrm{~cm} \mathrm{~s}^{-1}$ are shaded to indicate the TIBL.

FIG 8 - Temperature transects and $10 \mathrm{~m}$ time series from the coast and inland sites for the three cases in Fig. 7. Temperatures are shown on a different scale to sounder data. Temporal data for the inland site are shown by the dashed curves. The onset of the seabreeze is shown by squares in the wind direction trace. Inland temperature exceedances are shaded at bottom.

FIG $9-10 \mathrm{~m}$ network analyses of wind, temperature and sigma theta (top to bottom), at $13 \mathrm{~h} 00$ for the three cases corresponding to Figs 7 and 8 . Wind vector scale is shown at upper left. Units for temperature and sigma theta are ${ }^{\circ} \mathrm{C}$ and ${ }^{\circ}$ variance. 